\title{
Quality Managers' Estimates of Quality Management Principles Application in Certified Organisations in Transitional Conditions - Is Serbia Close to TQM?
}

\author{
Vladan Radlovački1,, - Ivan Beker1 - Vidosav Majstorović² - Mladen Pečujlija1- \\ Dragutin Stanivuković 1 - Bato Kamberović ${ }^{1}$ \\ ${ }^{1}$ University of Novi Sad, Faculty of Technical Sciences, Department for Industrial Engineering and \\ Management, Serbia \\ ${ }^{2}$ University of Belgrade, Faculty of Mechanical Engineering Belgrade, Department for Production \\ Engineering, Serbia
}

For this research, an ad hoc questionnaire was sent to a representative sample of quality managers in Serbian certified organisations to determine their estimate of the quality management principles application (QMPA) as an overall estimate of management commitment to quality management practice. In a stable business environment, high impact of TQM elements application to the QMPA is likely to be expected. Objective parameters (number of employees, form of ownership of organisation, etc.) are not likely to form significant variations in managers' perceptions of TQM elements.

It is determined that only a few of the selected TQM elements are predictors of a subjective estimate of the QMPA (estimates of QMS, changes after certification, human resource management and process management).

Observed objective parameters (number of employees and whether an organisation is employing a network administrator or not) showed statistically significant variations in estimates of TQM elements.

Research results point to the conclusion that Serbia is yet to take the long journey towards raising awareness about the management commitment to QM and TQM practice. It is possible that other economies in transition also have similar problems in this area.

(C2011 Journal of Mechanical Engineering. All rights reserved.

Keywords: TQM, quality management, questionnaire study, subjective estimate of TQM elements, management commitment, transition

\section{INTRODUCTION}

Approaches to quality improvement introduced by the quality gurus E. Deming, J. Juran, A. Feigenbaum, K. Ishikawa, G. Taguchi and P. Crosby represent the basis for classical TQM philosophy. However, the term »Total Quality Management« still does not have a uniformly accepted definition.

One of the definitions of TQM provided in $[1]$ is that $\gg \mathrm{TQM}$ is ... a collective, interlinked system of quality practices that is associated with organisational performance «. According to the same source, in the 1990s, TQM was mainly associated with meeting the requirements set by the Malcolm Baldrige National Quality Award (MBNQA). [2] defines TQM as "a holistic management philosophy that strives for continual improvement in all functions of an organisation", whereas [3] defines TQM as "a way of improving activities and performance in firms".

[4] defines TQM as "a strategy to meet customers' requirements" and "a management philosophy of seeking excellence in all aspects of business through organisation-wide continual improvement".

Analysis of the relevant literature indicates that researchers in the field of TQM used the same or similar methods in different regions. [5] were among the first to describe in detail and apply the methodology of analysing subjective opinions collected through questionnaires. The foundations for their questionnaire were the theoretical grounds of 1990s.

[1] investigated relations between TQM practice, organisation performance and customer satisfaction in the USA. [2] conducted research on TQM practices and their effects on company

*Corr. Author's Address: Faculty of Technical Sciences,

Trg Dositeja Obradovića 6, Novi Sad, Serbia, rule@uns.ac.rs 
performance in USA, where she described a number of previous similar researches in detail. [6] describes research of quality and innovation impact on the short-term performance of products in Spain, whereas [7] describes research in Spain about whether the organisations that implement TQM are better learning organisations. In Korea, [8] conducted research on the impact of MBNQA criteria on organisation quality performance. [9] published research on the effects of the certification process on organisation performance in Australia, [10] conducted similar empirical research in Malaysia as did [11] in Greece.

Analysis of these sources shows that implementation of TQM and a positive attitude towards TQM practice in a number of cases correlates to an increase of business performance, although the uniformly accepted impact of TQM implementation and company performance is not determined. Mixed results, as reported by [2], could exist for three groups of reasons: the design of research, the way performance is measured and the use of different analytical frameworks. [12] reported no findings of substantial differences of critical factors across different countries. However, they stated, the set of determined TQM key factors could not be considered as universal, primarily for the lack of information about a number of countries not covered by the research. Therefore, differences between countries might be a fourth factor to add to Kaynak's list. Expressed doubts related to universality do not influence the research for it is analysing subjective estimates on QMPA, not the key factors, or their impact to company performance.

\subsection{Research Problem}

[2] provides a thorough review of studies related to TQM. It includes a number of views about how TQM can be operationalised and analysed.

The aim of this research is to observe quality managers' subjective estimates of the quality management principles application (referred to as QMPA for the rest of the text) as an overall estimate of management commitment to QM and TQM. Focusing directly on estimates of QMPA is only a part of the research. Investigating relations between estimates of QMPA and estimates of other elements of TQM opeartionalisation is likely to provide a wider picture of how quality managers generally perceive TQM, and how organisations' managements are generally committed to TQM in the population observed. If managers are committed to TQM, it is likely to expect a correspondence between estimates of QM principles and TQM elements.

Quality management (QM) principles are defined in the ISO 9004 standard. The selection of TQM elements is treated later.

By thorough search of the available sources, it is determined that no systematic analyses related to the QMPA in Serbian organisations have been carried out so far. This research may provide some guidelines to managers willing to improve their business. Furthermore, it may provide some methodical innovations in the field.

\subsection{Operationalisation of TQM}

Economic systems in transition generally do not operate in a favourable business environment. The Serbian economy is generally characterised by unstable business conditions, mainly low motivation of managers for achieving business success beyond the struggle for survival, high stress level of both managers and other employees on all levels, use of outdated technology, instability of supply chains and many other unfavourable attributes.

The lack of valid information in Serbia about financial and other performance indicators of organisations, the absence of a central registry of certified organisations, the lack of benchmarking data, the unwillingness to participate in the research and other factors did not disable the research due to its focus on subjective estimates.

In order to carry out research to determine quality managers' estimates of QMPA as an overall estimate of management commitment to QM practice in Serbia, the fact that consistent implementation of QM principles should assure the application of TQM and most of business excellence criteria was used.

These principles [namely: a) customer focus, b) leadership, c) involvement of people, d) process approach, e) system approach to management, f) continual improvement, g) factual approach to decision-making and h) mutually be- 
neficial supplier relationships] are described and analysed in [13].

The estimates of TQM operationalisation elements used in the research are (relations to corresponding ISO 9001 requirements are also enclosed):

A Quality management principles application QMPA (proposed by the authors as a central element of the research),

B QMS - quality management system, ISO 9001 chapter (ch.) 4 (proposed by the authors to see how managers perceive QMS in general),

C key factors of QM success [12], ISO $9001 \mathrm{ch}$. 8.2 ,

D approaches to improvement ([14], [15], [16] and [3]), ISO $9001 \mathrm{ch} .5 .6,8.2,8.5$,

E changes after certification (proposed by the authors for information on how managers perceive benefits from the certification),

F application of QM techniques [17], ISO 9001 ch. 8.1,

G leadership ([16], [18], [19] and [3]), ISO 9001 ch. 5, 6, 7.1 and 7.5,

$\mathrm{H}$ quality/strategy planning ([20] and [3]), ISO 9001 ch. 5.4 and 7.1,

I human resource management ([21], [22], [20], [3] and [1]), ISO 9001 ch. 6.2,

$\mathrm{J}$ purchase management [3], ISO $9001 \mathrm{ch} .7 .4$,

$\mathrm{K}$ customer focus ([14], [15], [23], [16], [18], [19] and [3]), ISO 9001 ch. 5.2, 7.2, 7.5 and 8.2 ,

L process management ([14], [16], [22], [20] and [3]), ISO $9001 \mathrm{ch} .4 .1$ and 7,

$\mathrm{M}$ business results ([20] and [1]), ISO $9001 \mathrm{ch}$. 8.2 ,

$\mathrm{N}$ learning ([14], [23], [16] and [7]) and

$\mathrm{O}$ application of IT (proposed by the authors - information on the use level of IT in the population might provide relevant additional information).

While deciding on the construct, the idea was to focus to implementation of ISO 9001 requirements, not one-by-one, but as a whole. This is, in short, why some requirements are not directly addressed by the construct.

\subsection{Why Managers' Subjective Estimates}

The major problem when investigating the relations between TQM elements and business performance, as reported by [2], is obtaining the values of objective performance parameters of the companies. This problem is even more complex in Serbia today (problem is treated earlier).

Using the concept having the QMPA as the central point of the research enables exploring the interrelations of managers' estimates of different TQM elements and QMPA. Construct reliability/ validity test and findings of the research show that exploring exclusively perceptual data can provide valid and valuable results in the field.

This research is based on the data collected as a response from quality managers. [2] and [24] stated and confirmed that management leadership has a significant role in successful implementation of TQM practices and that management commitment support the motivation of employees to become more conscious of the need of a company to gain its goals. [2] reports of complaints from within the companies about the lack of management support and resistance to implement changes. The management commitment is, she determined, often weak or missing.

\section{RESEARCH HYPOTHESES}

Based on presented considerations, two general hypotheses as a basis for the model of the research were defined:

H01: Subjective estimates of TQM element application in an organisation may be statistically significant predictors of a subjective estimate of QMPA in an organisation and

H02: Relevant objective parameters of organisations may affect a subjective estimate of TQM elements.

Now, it is possible to establish the following specific operating hypotheses resulting from the general $\mathbf{H 0 1}$ hypothesis:

H1: Subjective estimate of QMS in organisations in general...

H2: Subjective estimate of QM success factors in organisations...

H3: Subjective estimate of current QM practice improvement approaches application in organisations...

H4: Subjective estimate of changes in organisations resulting from QMS implementation...

H5: Subjective estimate of the application of quality engineering techniques in organisations... 
H6: Subjective estimate of the application of leadership in organisations...

$\boldsymbol{H}$ 7: Subjective estimate of the application of quality and strategic planning in organisations...

H8: Subjective estimate of human resource management in organisations...

H9: Subjective estimate of purchase management in organisations...

H10: Subjective estimate of an organisation's focus on customers...

H11: Subjective estimate of process management...

H12: Subjective estimate of business results and analyses in organisations...

H13: Subjective estimate of learning in organisations...

H14: Subjective estimate of information technologies (IT) application as a support to the information system and QMS in organisations...

... may be a statistically significant predictor of a subjective estimate of QMPA.

It is also possible to establish the following specific operating hypotheses resulting from the general hypothesis H02:

H15: The number of employees in organisations...

H16: The form of organisation ownership...

H17: The nature of organisations (production/ service/combined)...

H18: The existence of a computer network, with an employed network administrator in an organisation...

H19: The use of database and business applications in daily operation... elements.

... may affect a subjective estimate of TQM

A graphic presentation of the model resulting from the general hypothesis $\mathbf{H 0 1}$ is shown in Fig. 1.

\section{DESCRIPTION OF THE QUESTIONNAIRE}

For the purpose of the research, a questionnaire containing 147 questions divided into 15 groups (scales) was created.

Estimates are defined according to the discrete Likert-type scale.

The content validity of the questionnaire was carried out through subjective evaluation as in [3]. The items were considered as suitable because they were obtained from the literature reviews, in accordance with the goals of the research and characteristics of the population.

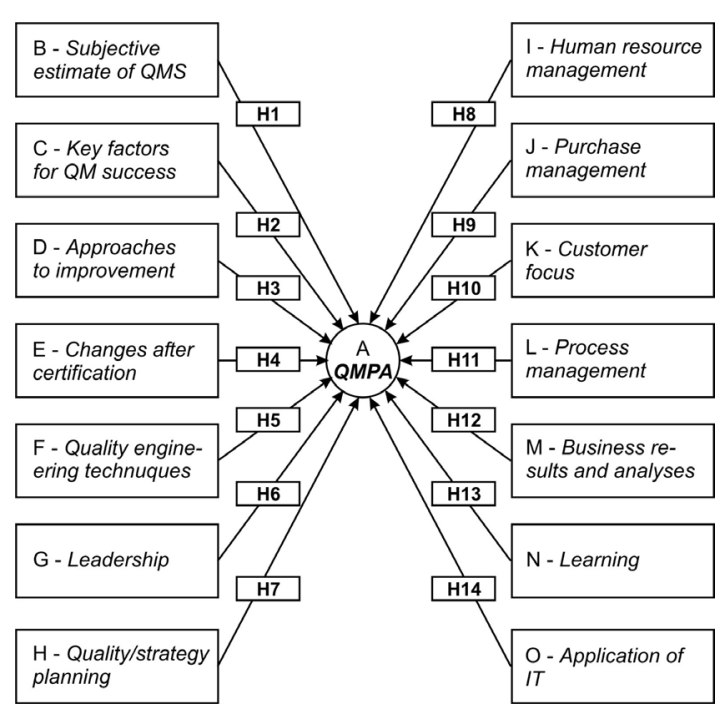

Fig. 1. Graphic presentation of the model resulting from $\mathrm{HO} 1$

Values of Cronbach's $\alpha$ coefficients obtained by scale validity testing are given with each scale in the following text. All scales proved to be reliable $(\alpha>0.7,[4])$, as well as each of the items in the questionnaire.

Scale QMPA (A, $\alpha=0.802$ ) consists of 13 items which refer to a subjective estimate of QMPA in an organisation. This scale is a central scale of the research.

The scale "Estimate of QMS" (B, $\alpha=$ 0.738 ) consists of 8 items. An important factor of TQM application is the manner in which quality managers perceive benefits of the quality management system.

The scale "Key factors for QM success" $(\mathrm{C}, \alpha=0.776)$ consists of 9 items - estimates whether process management, informing in QMS, employees interrelations, relations with users and other elements are key factors of QM success.

The scale "Approaches to improvement" $(\mathrm{D}, \alpha=0.754)$ consists of 5 items about standard approaches to management system improvement (internal audit, corrective and preventive actions and management review).

The scale "Changes after certification" (E, $\alpha=0.938$ ) consists of 18 items related to changes that were the result of the application of ISO 9001:2008 standard requirements (within first years after certification).

The scale "Quality engineering techniques" (F, $\alpha=0.942$ ) consists of 12 items about quality 
engineering techniques application. Scales G $\mathrm{N}$ refer to a subjective estimate of organisation orientation towards gaining TQM. Those are: "Leadership" (G, 8 items, $\alpha=0.937$ ), "Quality/strategic planning" ( $\mathrm{H}, 11$ items, $\alpha=0.927)$, "Human resource management" (I, 6 items, $\alpha=$ 0.872), "Purchase management" (J, 2 items, $\alpha=$ 0.852), "Customer focus" (K, 7 items, $\alpha=0.795)$, "Process management" (L, 7 items, $\alpha=0.769)$, "Business results and analyses" (M, 6 items, $\alpha=$ 0.831 - practically, the trends of user satisfaction, profitability, employee satisfaction, business trends, productivity and performance measuring system effectiveness) and "Learning" (N, 3 items, $\alpha=0.770$ ).

The last one - "Application of IT" - refers to IT application as a support to the organisation information system (O, 32 items, $\alpha=0.926)$.

\section{SAMPLE AND DATA}

The questionnaire was sent for completion to management representatives in 204 certified organisations. 51 completed questionnaires (25\%) were sent back.

Among organisations that submitted completed surveys, 12 are exclusively production organisations $(23.5 \%), 14$ organisations $(27.5 \%)$ with combined core operations (both production and services) and 25 organisations (49\%) exclusively providing services.

Seven organisations $(13.73 \%)$ have from 1 to 9 employees, 17 organisations (33.33\%) have from 10 to 49 employees, 23 organisations $(45.10 \%)$ have from 50 to 249 employees and 4 organisations $(7.84 \%)$ have 250 and more employees.

Among the respondents, 33 organisations $(64.7 \%)$ are private property, 15 organisations $(29.4 \%)$ are state property and 2 organisations (3.9\%) are combined property.

The average age of QMS in the sample is 4.07 years, while $\sigma$ is 2.78. Certification of the quality management system from the sample took place at least 1 year, or at the most 13 years before the survey.

\section{RESULTS AND DISCUSSION}

Descriptive statistics are presented in Table 1. Respondents filled in $96.49 \%$ of the questionnaire items.

The highest mean is in scale $\mathrm{K}$ - Customer focus (4.46), and the lowest mean is in scale F Application of quality engineering techniques (2.20). Table 1 presents all the scales of the questionnaire descriptors sorted descending by the mean.

\subsection{Variations by Independent Variables}

The significant impact on estimates of TQM elements is present in the following cases: the number of employees (on three scales), and the existence of a computer network with an employed network administrator (as much as on 11 scales).

Table 1. Scales descriptive statistics

\begin{tabular}{|c|l|c|c|}
\hline No & \multicolumn{1}{|c|}{ Scales } & $\begin{array}{c}\text { Mean } \\
\text { (sorted, } \\
\text { desc. }\end{array}$ & $\sigma$ \\
\hline 1 & K Customer focus & 4.46 & 0.75 \\
\hline 2 & J Purchase management & 4.44 & 1.13 \\
\hline 3 & G Leadership & 4.31 & 1.05 \\
\hline 4 & A QMPA & 4.21 & 0.91 \\
\hline 5 & N Learning & 4.20 & 1.00 \\
\hline 6 & $\begin{array}{l}\text { C Key factors for QM } \\
\text { success }\end{array}$ & 4.17 & 1.08 \\
\hline 7 & L Process management & 4.17 & 0.98 \\
\hline 8 & $\begin{array}{l}\text { H Quality/strategy } \\
\text { planning }\end{array}$ & 4.05 & 1.12 \\
\hline 9 & $\begin{array}{l}\text { I Human resource } \\
\text { management }\end{array}$ & 4.05 & 1.04 \\
\hline 10 & $\begin{array}{l}\text { E Changes after } \\
\text { certification }\end{array}$ & 3.91 & 1.17 \\
\hline 11 & O Application of IT & 3.88 & 1.68 \\
\hline 12 & B Estimate of QMS & 3.87 & 1.08 \\
\hline 13 & $\begin{array}{l}\text { M Business results and } \\
\text { analyses }\end{array}$ & 3.84 & 1.24 \\
\hline 14 & $\begin{array}{l}\text { D Approaches to } \\
\text { improvement }\end{array}$ & $\begin{array}{l}\text { F Quality engineering } \\
\text { techniques }\end{array}$ & 2.20 \\
\hline
\end{tabular}

Other independent parameters (the nature of an organisation's business, the use of databases 
Table 2. One-way ANOVA - Scales by independent: number of employees

\begin{tabular}{|c|c|c|c|c|c|c|}
\hline & Sum of Squares & $d f$ & Mean Square & $F$ & Sig. \\
\hline \multirow{3}{*}{$\begin{array}{l}\text { B Estimate of } \\
\text { QMS }\end{array}$} & Between Groups & 208.010 & 3 & 69.337 & 3.256 & .030 \\
\hline & Within Groups & 1000.813 & 47 & 21.294 & & \\
\hline & Total & 1208.824 & 50 & & & \\
\hline \multirow{3}{*}{$\begin{array}{l}\text { D Approaches } \\
\text { to } \\
\text { improvement }\end{array}$} & Between Groups & 219.804 & 3 & 73.268 & 4.500 & .007 \\
\hline & Within Groups & 765.177 & 47 & 16.280 & & \\
\hline & Total & 984.980 & 50 & & & \\
\hline \multirow{3}{*}{$\begin{array}{l}\text { M Business } \\
\text { results and } \\
\text { analyses }\end{array}$} & Between Groups & 411.968 & 3 & 137.323 & 5.832 & .002 \\
\hline & Within Groups & 1106.777 & 47 & 23.548 & & \\
\hline & Total & 1518.745 & 50 & & & \\
\hline \multirow{3}{*}{$\begin{array}{l}\text { O Application } \\
\text { of IT }\end{array}$} & Between Groups & 5475.404 & 3 & 1825.135 & 2.780 & .051 \\
\hline & Within Groups & 30853.772 & 47 & 656.463 & & \\
\hline & Total & 36329.176 & 50 & & & \\
\hline
\end{tabular}

and form of ownership) do not have a statistically significant impact on TQM elements.

Testing of the $\mathrm{H} 02$ showed that it could be accepted to a limited extent. Hypothesis H16, H17 and $\mathrm{H} 19$ are not confirmed.

\subsubsection{Number of Employees (Hypothesis H15)}

Table 2 presents the results of the analysis. A statistically significant impact on the scales B, $\mathrm{D}, \mathrm{M}$ and $\mathrm{O}$ was determined. $P$-value for the scale $\mathrm{O}$ (slightly over 0.05 ) indicates that the impact of the number of employees on the scale $\mathrm{O}$ may conditionally be considered as significant.

Hypothesis H15 may be considered as confirmed to a limited extent.

\subsubsection{Employed Network Administrator (Hypothesis H18)}

The results of the analysis are presented in Table 3. A statistically significant impact on the scales A, B, C, D, E, I, K, L, M, N and $\mathrm{O}$ was determined.

The observed independent parameter shows a significant impact on subjective estimates of the TQM elements application. H18 is largely confirmed.

\subsection{Predictors of a Subjective Estimate of the QM Principles Application (Scale A)}

The calculation (Table 4) shows that the regression model is fully statistically significant.
The linear regression analysis (Table 5) showed that the scales B, C, E, I and L are statistically significant predictors of a subjective estimate of QMPA.

\subsection{Interpretation of Results}

\subsubsection{Comments on H01 Validation}

The existence of high means might be attributed to the lack of proper information about the business excellent system, rather than to high QM performance of organisations from the sample.

Fig. 2 presents the results of regression model calculations obtained by testing general hypothesis $\mathrm{H} 01$.

Expected impacts of B, E, I and L scales on a subjective estimate of QMPA have been registered. Subjective estimates of QMS, changes after certification, human resource management and process management in an organisation are predictors of a subjective estimate of QMPA in Serbia.

Therefore, quality managers in Serbia estimate that, by certification, organisations have accomplished some of the main objectives - improved process management, enhanced subjective estimate of the system, gained substantial changes in an organisation and improved human resource management.

However, the research shows that the fulfilment of customer requirements in Serbia seems not to be related to QMPA, i.e. not applied. It 
Table 3. One-way ANOVA - Scales by independent: existence of an employed network administrator

\begin{tabular}{|c|c|c|c|c|c|c|}
\hline & & Sum of Squares & $d f$ & Mean Square & $F$ & Sig. \\
\hline \multirow{3}{*}{ A QMPA } & Between Groups & 335.324 & 2 & 167.662 & 5.318 & .008 \\
\hline & Within Groups & 1513.265 & 48 & 31.526 & & \\
\hline & Total & 1848.588 & 50 & & & \\
\hline \multirow{3}{*}{ B Estimate of QMS } & Between Groups & 220.390 & 2 & 110.195 & 5.351 & .008 \\
\hline & Within Groups & 988.434 & 48 & 20.592 & & \\
\hline & Total & 1208.824 & 50 & & & \\
\hline \multirow{3}{*}{$\begin{array}{l}\text { C Key factors for } \\
\text { QM success }\end{array}$} & Between Groups & 193.105 & 2 & 96.553 & 3.544 & .037 \\
\hline & Within Groups & 1307.875 & 48 & 27.247 & & \\
\hline & Total & 1500.980 & 50 & & & \\
\hline \multirow{3}{*}{$\begin{array}{l}\text { D Approaches to } \\
\text { improvement }\end{array}$} & Between Groups & 225.570 & 2 & 112.785 & 7.129 & .002 \\
\hline & Within Groups & 759.410 & 48 & 15.821 & & \\
\hline & Total & 984.980 & 50 & & & \\
\hline \multirow{3}{*}{$\begin{array}{l}\text { E Changes after } \\
\text { certification }\end{array}$} & Between Groups & 2167.716 & 2 & 1083.858 & 6.304 & .004 \\
\hline & Within Groups & 8252.441 & 48 & 171.926 & & \\
\hline & Total & 10420.157 & 50 & & & \\
\hline \multirow{3}{*}{$\begin{array}{l}\text { I Human resource } \\
\text { management }\end{array}$} & Between Groups & 153.497 & 2 & 76.748 & 4.231 & .020 \\
\hline & Within Groups & 870.660 & 48 & 18.139 & & \\
\hline & Total & 1024.157 & 50 & & & \\
\hline \multirow{3}{*}{ K Customer focus } & Between Groups & 119.782 & 2 & 59.891 & 5.728 & .006 \\
\hline & Within Groups & 501.904 & 48 & 10.456 & & \\
\hline & Total & 621.686 & 50 & & & \\
\hline \multirow{3}{*}{$\begin{array}{l}\text { L Process } \\
\text { management }\end{array}$} & Between Groups & 172.188 & 2 & 86.094 & 5.396 & .008 \\
\hline & Within Groups & 765.851 & 48 & 15.955 & & \\
\hline & Total & 938.039 & 50 & & & \\
\hline \multirow{3}{*}{$\begin{array}{l}\text { M Business results } \\
\text { and analyses }\end{array}$} & Between Groups & 267.585 & 2 & 133.793 & 5.133 & .010 \\
\hline & Within Groups & 1251.160 & 48 & 26.066 & & \\
\hline & Total & 1518.745 & 50 & & & \\
\hline \multirow{3}{*}{ N Learning } & Between Groups & 63.429 & 2 & 31.714 & 6.361 & .004 \\
\hline & Within Groups & 239.316 & 48 & 4.986 & & \\
\hline & Total & 302.745 & 50 & & & \\
\hline \multirow{3}{*}{ O Application of IT } & Between Groups & 18321.294 & 2 & 9160.647 & 24.418 & .000 \\
\hline & Within Groups & 18007.882 & 48 & 375.164 & & \\
\hline & Total & 36329.176 & 50 & & & \\
\hline
\end{tabular}

Table 4. Regression model

\begin{tabular}{|c|l|c|c|c|c|c|}
\hline \multicolumn{2}{|c|}{ Model } & Sum of Squares & $d f$ & Mean Square & $F$ & Sig. \\
\hline \multirow{3}{*}{1} & Regression & 1610.103 & 14 & 115.007 & 17.361 & $.000^{\mathrm{a}}$ \\
\cline { 2 - 7 } & Residual & 238.485 & 36 & 6.625 & & \\
\cline { 2 - 7 } & Total & 1848.588 & 50 & & & \\
\hline
\end{tabular}

perfectly corresponds to the estimate of the application of quality engineering methods and techniques. The mean of the scale $F$ is by far the lowest in the questionnaire (Table 1). [14] found no significant impact of continuous improvement and customer satisfaction (15 years ago).
The estimate of key factors for QM success is a predictor of an estimate of QMPA, which indicates to the validity of hypothesis $\mathrm{H} 2$, but seems to be a paradox for $\beta<0$. Managers in Serbia estimate that $\mathrm{QM}$ systems are more successful if QM principles are less applied. 
Table 5. Predictors of a subjective estimate of QMPA

\begin{tabular}{|c|c|c|c|c|c|c|}
\hline & \multirow[t]{2}{*}{ Model } & \multicolumn{2}{|c|}{$\begin{array}{c}\text { Unstandardized } \\
\text { Coefficients } \\
\end{array}$} & \multirow{2}{*}{$\begin{array}{c}\begin{array}{c}\text { Standardized } \\
\text { Coefficients }\end{array} \\
\beta \\
\end{array}$} & \multirow[t]{2}{*}{$t$} & \multirow[t]{2}{*}{ Sig. } \\
\hline & & $B$ & Std. Error & & & \\
\hline \multirow{15}{*}{1} & (Constant) & 13.680 & 3.845 & & 3.558 & .001 \\
\hline & O Application of IT & -.011 & .023 & -.050 & -.488 & .629 \\
\hline & N Learning & .046 & .290 & .018 & .157 & .876 \\
\hline & M Business results and analyses & -.044 & .092 & -.039 & -.474 & .638 \\
\hline & L Process management & .338 & .151 & .241 & 2.235 & .032 \\
\hline & K Customer focus & .130 & .170 & .076 & .768 & .448 \\
\hline & J Purchase management & .410 & .218 & .142 & 1.886 & .067 \\
\hline & I Human resource management & .492 & .113 & .366 & 4.367 & .000 \\
\hline & H Quality/strategy planning & -.182 & .101 & -.266 & -1.797 & .081 \\
\hline & G Leadership & .106 & .117 & .122 & .907 & .370 \\
\hline & F Quality engineering techniques & -.010 & .031 & -.023 & -.317 & .753 \\
\hline & E Changes after certification & .178 & .040 & .423 & 4.443 & .000 \\
\hline & D Approaches to improvement & .026 & .124 & .019 & .209 & .836 \\
\hline & C Key factors for QM success & -.241 & .099 & -.217 & -2.438 & .020 \\
\hline & B Estimate of QMS & .481 & .115 & .389 & 4.200 & .000 \\
\hline
\end{tabular}

Reasons for this finding are likely to be found in the aspirations of managers in Serbia and their familiarity with the purpose of QMPA. It is highly likely that mechanisms of internal audits, corrective and preventive actions and management review are usually conducted for formal reasons (scale D is not a predictor of QMPA). Having in mind the findings of [2] ("management's lack of support, its resistance to change ... make it difficult to cultivate and take advantage of opportunities for TQM's potential benefits"), findings of the research so far give an impression that managers in Serbia are still not significantly committed to QM, TQM and continuous improvement. Some useful findings about the relationship between internal and external audits and number of employees of a company are given in [25].

Quality engineering techniques are implemented poorly in Serbia. If validated methods are not used, then everything that is done is just a response to a situation, not the result of planning. This also corresponds to the observed findings (scale $H$ is not a predictor of QMPA). Achieving continuous quality improvement implies the use of appropriate quality tools and techniques (as stated in [26]) and should be the obligatory aim in gaining leadership.

The subjective estimate of the leadership in organisations is also not a predictor of a sub- jective estimate of QMPA. The reasons are most likely very complex and detailed research thereof is beyond the scope of the research.

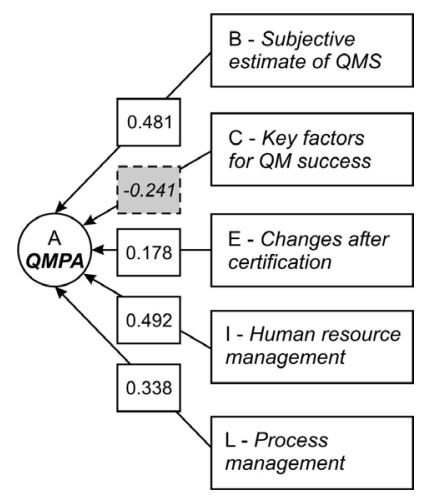

Fig. 2. Regression analysis results

Quality managers should be aware of the need for the implementation of quality engineering techniques.

A subjective estimate of quality and strategic planning has not proved to be a predictor of QMPA either. Planning in unfavourable conditions is much more complicated than planning in stable conditions.

The described findings imply the lack of awareness of these important relations between business success and QMPA in Serbia. 
The part of the questionnaire related to human resource management, mostly treats basic requirements - training and employees' attitudes. These elements are predictors of QMPA. However, keeping in mind that these elements are obligatory for the certification, the management is pressed to implement them and quality managers are involved.

As the price is usually the strongest (often the only) criterion for purchase in Serbia, it is probably the reason for not having purchase management as a significant predictor of QMPA.

Estimates of learning have also not proved to be a predictor of QMPA. However, it cannot be said that there is no on-the-job training - business simply could not be continually conducted in such conditions. The cause may be in training sessions that are often conducted ad hoc, and are not recorded (the effectiveness thereof is evaluated rarely in Serbian organisations). To implement learning appropriately in an organisation and aim it to gain better performance, managers should create constructive environment and motivate their employees - this is also a part of management commitment [2].

According to the authors' experience, it is rare to see an example of effective IT application in Serbia today. The research has shown that the estimated level of IT application is also not a predictor of a subjective estimate of QMPA.

\subsubsection{Comments on HO2 Validation}

Two out of 6 independent parameters show statistically significant variations.

The number of employees influences estimates of QMS (B), approaches to improvement (D), business results (M) and the application of IT (O). Estimates significantly rise from micro to large organisations for all of the above. Managers of micro and small organisations may use this result to consider enhancing approaches to QMS improvement and IT efficiency. On the other hand, managers' estimates of QMPA, quality planning, human resource management and other elements do not depend on organisational size. New research might offer an insight into the causes and implications of these findings.

Taking into account the question of whether an organisation has a network administrator employed or not proved to be very informative.
Here, the parameter is not blurred by subjectivity (as it probably is with the use of databases) - an organisation simply employs administrator(s) or it does not. Estimates of almost every TQM element (even the one this research is focused on - QMPA) show variations related to this parameter, and are higher if the organisation employs administrator. This is likely the consequence of the fact that decisionmaking based on facts derived from information systems is better when a network is administered from within the organisation. On the other hand, decision-making and QMS efficiency are closely related. Therefore, managers in Serbia can use these findings to consider employing a network administrator (or improving administering) for improving QMS efficiency. The efficiency of internal communications is a requirement of the ISO 9001 standard. Enhancing the information system is likely to provide better QMS. [27] report tight connections between TQM and IT in their detailed research.

\section{CONCLUSIONS AND DIRECTIONS OF FURTHER RESEARCH}

This is, to the knowledge of authors, the first systematic review of TQM practice in Serbia.

The research has reached its aim and it has provided conclusions useful for both practitioners and researchers.

Estimates of the quality management principles application (QMPA) uncover the lack of awareness in an organisation's management about the importance of applying QMPA, commitment to QM and, therefore, applying continuous improvements. It also contains observations on where to find some of the reasons for the treated standing of TQM practice (both subjective - the lack of the managers' awareness being one of the most important - and objective - the need for a more favourable organisational environment) in further research.

Findings have shown that it is possible to do valid research in the field based on subjective estimates of TQM elements only. The phase of construct validity using Cronbach alpha coefficients proved the items and scales are valid, as well as the regression model test. Furthermore, the determined importance of administering 
computer networks and its impact to TQM elements empirically supports the validity of the model used.

Research results have also shown that the use of the QM principles application (QMPA) in the analysis of subjective estimates as a central point led to valid and valuable results.

It was not the intention of this research to explore the relationship between TQM practices and objective parameters of TQM performance. This is the most significant drawback of the research. Keeping in mind the characteristics of the environment organisations operate in now, it is, at least, extremely difficult (if not impossible) to do more thorough research. Even in developed regions, managers are rarely willing to share these data with researchers [2].

It is not clear how "close" Serbia is to TQM, but it is obvious that the given attribute cannot illustrate the present standings. The "way" Serbia has to pass certainly goes through many points. Fostering the managers' commitment to $\mathrm{QM}$ and TQM is one of them.

The study does not treat problems of integrating other management systems in QMS (such as environmental, OH\&S) and their relations to QMPA. It does also not include any observations about the management of secondary materials and recycling (treated in detail in [28]), applying six-sigma, statistical and quality engineering techniques, and a number of other work process improvements, to increase performance and competitiveness. Some of these may be the subject of future research of TQM practice in Serbia on the way to improvement. Managers are strongly advised to apply complex improvements using project strategies [29].

\section{REFERENCES}

[1] Choi, T.Y., Eboch, K. (1998). The TQM Paradox: Relations among TQM practices, plant performance, and customer satisfaction. Journal of Operations Management, vol. 17, no. 1, p. 59-75.

[2] Kaynak, H. (2003). The relationship between total quality management practices and their effects on firm performance. Journal of Operations Management, vol. 21, no. 4, p. 405-435.
[3] Tarí, J.J., Molina, J.F., Castejón, J.L. (2007). The relationship between quality management practices and their effects on quality outcomes. European Journal of Operational Research, vol. 183, no. 2, p. 483-501.

[4] Han, S.B., Chen, S.K., Ebrahimpour, M. (2007). The Impact of ISO 9000 on TQM and Business Performance. Journal of Business and Economic Studies, vol. 13, no. 2, p. 1-23.

[5] Flynn, B.B., Schroeder, R.G., Sakakibara, S. (1994). A framework for quality management research and an associated measurement instrument. Journal of Operations Management, vol. 11, no. 4, p. 339-366.

[6] Molina-Castillo, F.J., Munuera-Aleman, J. L. (2009). The joint impact of quality and innovativeness on short-term new product performance. Industrial Marketing Management, vol. 38, no. 8, p. 984-993.

[7] Martinez-Costa, M., Jiménéz-Jiménéz, D. (2008). Are companies that implement TQM better learning organisations? An empirical study. Total Quality Management \& Business Excellence, vol. 19, no. 11, p. 1101-1115.

[8] Lee, S.M., Rho, B.H., Lee, S.G. (2003). Impact of Malcolm Baldrige National Quality Award Criteria on organizational quality performance. International Journal of Production Research, vol. 41, no. 9, p. 2003-2020.

[9] Terziovski, M., Power, D., Sohal, A.S. (2003). The longitudinal effects of the ISO 9000 certification process on business performance. European Journal of Operational Research, vol. 146, no. 3, p. 580-595.

[10] Agus, A., Sagir, R.M. (2001). The structural relationships between total quality management, competitive advantage and bottom line financial performance: An empirical study of Malaysian manufacturing companies. Total Quality Management, vol. 12 , no. 7-8, p. 1018-1024.

[11] Tsekouras, K., Dimara, E., Skuras, D. (2002). Adoption of a quality assurance scheme and its effect on firm performance: 
A study of Greek firms implementing ISO 9000. Total Quality Management \& Business Excellence, vol. 13, no. 6, p. 827-841.

[12] Sila I., Ebrahimpour M. (2003). Examination and comparison of the critical factors of total quality management (TQM) across countries. International Journal of Production Research, vol. 41, no. 2, p. 235268

[13] West, J., Cianfrani, C.A., Tsiakals, J.J. (2000). Quality management principles: Foundation of ISO 9000:2000 family. Quality Progress, vol. 33, no. 2, p. 113-117.

[14] Anderson, J., Rungtusanatham, M., Schroeder, R.O., Devaraj, S. (1995). A path analytic model of a theory of quality management underlying the deming management method: Preliminary empirical findings. Decision Sciences, vol. 26, no. 5, p. $637-658$

[15] Mohrman, S.A., Tenkasi, R.V., Lawler III, E.E., Ledford Jr., G.G. (1995). Total quality management: practice and outcomes in the largest US firms. Employee Relations, vol. 17 , no. 3, p. 26-41

[16] Grandzol, J.R., Gershon, M. (1997). Which TQM practices really matter: an empirical investigation. Quality Management Journal, vol. 4 , no. 4 , p. 43-59.

[17] Tarí, J.J., Sabater, V. (2003). Quality tools and techniques: Are they necessary for quality management?. International Journal of Production Economics, vol. 92, no. 3, p. 267-280.

[18] Dow, D., Samson, D., Ford, S (1999). Exploding the myth: do all quality management practices contribute to superior quality performance?. Production and Operations Management, vol. 8, no. 1, p. 1-27.

[19] Samson, D., Terziovski, M. (1999). The relationship between total quality management practices and operational performance. Journal of Operations Management, vol. 17, no. 4, p. 393-409.

[20] Wilson, D.D., Collier, D.A. (2000). An empirical investigation of the Malcolm Baldrige National Quality award causal model. Decision Sciences, vol. 31, no. 2, p. 361-390.
[21] Powell, T.C. (1995). Total quality management as competitive advantage: a review and empirical study. Strategic Management Journal, vol. 16, no. 1, p. 1537.

[22] Forza, C., Flippini, R. (1998). TQM impact on quality conformance and customer satisfaction: a causal model. International Journal of Production Economics, vol. 55, no. 1, p. 1-20.

[23] Adam Jr., E.E., Corbett, L.M., Flores, B.E., Harrison, N.J., Lee, T.S., Rho, B.H., Ribera, J., Samson, D., Westbrook, R. (1997). An international study of quality improvement approach and firm performance. International Journal of Operations and Production Management, vol. 17, no. 9, p. 842-873.

[24] Conca, F.J., Llopis, J., Tari, J.J. (2004). Development of a measure to assess quality management in certified firms. European Journal of Operational Research, vol. 156, no. 3, p. 683-697.

[25] Maglić, L., Kondić, Z., Kljajin, M. (2009). Quality Audits of Management Systems. Strojniški vestnik - Journal of Mechanical Engineering, vol. 55, no. 11, p. 695-700.

[26] Soković, M., Jovanović, J., Krivokapić, Z., Vukjović, A. (2009). Basic Quality Tools in Continuous Improvement Process. Strojniški vestnik - Journal of Mechanical Engineering, vol. 55, no. 5, p. 333-341.

[27] Fok, L.Y., Fok, W.M., Hartman, S.J. (2001). Exploring the relationship between total quality management and information systems development. Information \& Management, vol. 38, no. 6, p. 355-371.

[28] Simpson, D. (2010). Use of supply relationships to recycle secondary materials. International Journal of Production Research, vol. 48, no. 1, p. 227-249.

[29] Poli, M., Cosić, I., Lalić, B. (2010). Project strategy: Matching project structure to project type to achieve better success. International journal of industrial engineering and management, vol. 1, no. 1, p. 29-40. 